\title{
CORRESPONDENCE
}

\section{Mercury in Lakes}

SiR,-Recently, Aston et al. ${ }^{1}$ reported that the mercury concentrations within a sediment core from an English lake were highest in the upper layers of sediment. Others $\mathrm{s}^{2,3}$ have reported similar findings. All have attributed this differential distribution in part to the possibility of increased inputs of mercury with time due to man's activities.

Although there has been some discussion as to the source of this input $t^{4,5}$, a lingering problem involves demonstrating that mercury levels in organisms have become generally elevated. Several researchers ${ }^{6-8}$ have compared mercury levels in old and recent biological samples and could not document a general increase of mercury content in life forms as time passed. It may be, then, that mercury levels have always been highest in upper sediment layers.

Aquatic organisms can concentrate mercury in their bodies. When they die, sink, and decompose, they would add significant amounts of mercury to the upper sediments. The life cycle of benthic insects offers a particularly striking pathway whereby mercury could be carried upward and ultimately deposited at the sediment-water interface. There is some evidence that tubificid worms could carry substances upward in sediments. Some fish and algae are known to have high mercury loads. Death and decomposition of these organisms would increase the mercury content of upper sediments.
In short, the activity and death of aquatic organisms would continually cycle mercury to the upper sediment layers.

As others have mentioned ${ }^{1,2}$, several researchers have proposed a geochemical mechanism whereby mercury diffuses upward in sediments. This too may enhance the occurrence of elevated mercury levels in upper sediment layers.

Except in sediments from known mercury contamination areas, the phenomenon that mercury concentrations tend to be highest in upper sediment layers may be a natural condition and not attributable to recent inputs of mercury.

Yours faithfully,

C. S. Sikes

M. P. Drain

Department of Biology,

John Carroll University,

Cleveland, Ohio 44118

${ }^{1}$ Aston, S. R., Bruty, D., Chester, R., and Padgham, R. C., Nature, 241, 450 (1973).

${ }^{2}$ Walters, L. J., Charles, E., Herdendorf, L., Charlesworth, jun., J., Anders, H. K., Jackson, W. P., Skoch, E. J., Webb, D. K., Kovacik, T. L., and Sikes, C. S., Proceedings of the Fifteenth Conference on Great Lakes Research, 306 (1972).

${ }^{3}$ Kennedy, E. J., Ruch, R. R., and Shimp, N. F., Illinois State Geologic Survey, Environmental Geology Note, 44, 18 (1971).

4 Joensuu, O. I., Science, 172, 1027 (1971).

5 Billings, C. E., and Matson, W. R., Science, 176, 1232 (1972).

${ }^{6}$ Miller, G. E., Grant, P. M., Kishore, K. Steinkruger, P. J., Rowland, F. S., and Guinn, V. P., Science, 175, 1121 (1972).
7 Barber, R. T., Vijayakumar, A., and Cross, F. A., Science, 178, 636 (1972).

8 Kevorkian, J., Cento, D. P., Hyland, J. R. Bagozzi, W. M., and van Hollebeke, E., J. Pub. Health, 62, 504 (1972).

9 Brinkhurst, R. O., USEPA, Ecological Research Series, Project 16010 ECQ, 68 (1972).

\section{Solar Energy}

SiR,-The International Solar Energy Society was formed in 1954 to serve as a centre for information on research and development in the utilization of solar energy. The Society headquarters are in Melbourne, Australia ; in countries where sufficient interest exists, national sections of the Society have been established.

At present, there is no British section, although there are nearly enough individual members to allow the formation of one. If such a section were formed it would, by means of newsletters and meetings, bring together British scientists, engineers and environmentalists whose work involves the nature and use of solar energy.

I am assessing the possibility of forming a British section. I should be very grateful to receive any comments, or to send further details of the ISES to anyone who is interested.

Yours faithfully,

M. D. ARChER

The Royal Institution

21 Albemarle Street,

London W1X $4 B S$

\section{Obituary}

\section{Dr Muriel Robertson}

Dr MURIEL RobERTSON, FRS, who died on June 20 at the age of ninety, was educated at Glasgow University, where she graduated as an MA in 1905 and which subsequently awarded her a DSc and, in 1948, an LID. She spent three years as a Carnegie Research Fellow in Ceylon, studying various parasitic Protozoa in the blood of reptiles and fishes. Thus she was introduced to the trypanosomes, a group on which much of her subsequent research was to be done. She discovered and named a trypanosome of a turtle and studied its complete life cycle in both vertebrate and invertebrate hosts (leeches). This was one of the first life histories of a member of this genus to be elucidated in detail.

Dr Robertson then returned to Britain in 1909 to work for a year as research assistant to Professor E. A. Minchin at the Lister Institute, and subsequently joined the Institute's staff. No doubt it was from Professor Minchin that she acquired much of the cytological expertise she was later so fruitfully to apply to her studies of trypanosomes and other protozoa. In 1911 her wanderlust reasserted itself, and she joined the Royal Society's Sleeping Sickness Commission in Uganda, under $\mathrm{Dr}$
H. L. Duke, as Protozoologist to the Uganda Protectorate. Travel to such relatively unknown regions as central Africa was not commonly undertaken by young ladies in the early years of this century, and Dr Robertson's achievements in this field testify to her adventurous and determined nature, exemplified also perhaps by her use of a bicycle as a means of transport through the forests of southern Uganda.

This period could perhaps be regarded as the acme of her scientific career, when she worked out in detail the entire, complicated developmental cycle undergone by Trypanosoma gambiense, the causative organism of human sleeping sick- 
ness, which was at that time devastating the population on the northern shore of Lake Victoria. This work, published mainly in the Proceedings of the Royal Society, involved cytological studies of extreme delicacy and her beautifully illustrated papers are undoubted classics. Her work on this subject has never been superseded nor indeed cqualled, and the accuracy of some of her conclusions (for example, the role of the stumpy blood-stream trypomastigote in infecting the vector, Glossina spp.) is only now being fully appreciated.

After this period Dr Robertson returned to the Lister Institute in 1915 as protozoologist, a post which she occupied for the remainder of her working life, which continued until she was at least 78. During the First World War she showed her versatility by making valuable studies, eminently practical at that time, of the anaerobic bacteria causing gas gangrene, and she became secretary of the Medical Research Council's first Anaerobes Committee and a contributor to the Council's System of Bacteriology. Later, she returned to her first scientific loves, the protozoa, continuing her elegant cytological studies on the free living flagellate Bodo and on the finer details of nuclear structure and division in Trypanosoma. Miss Robertson's practical nature reasserted itself and she began a long series of pioneering studies of the host's immune response to the parasite Trichomonas foetus, an economically important cause of bovine abortion. This work was summarized in her contribution to the book Immunity to Protozoa, published in 1963 when Miss Robertson was 80 . She celebrated her 80 th birthday by delivering the sixth Marjory Stephenson Memorial Lecture to the Society for
General Microbiology, in which she discussed the cytology, life cycles and what she referred to as "the highly experimental approach ... to sex" of her beloved protozoa. In this wide ranging review she showed a wholly typical grasp of modern techniques by referring to electron-microscope observations as well as to her own pioneering researches and to the work of many others, spanning the intervening halfcentury. Her scientific achievements were recognized by her election to an FRS in 1947.

Everyone who met Dr Robertson was impressed by her kindliness, her willingness to impart knowledge, her enthusiasm for her subject and her forthright personality. She belonged to a generation of female scientific explorers which was probably unique. Not only will she be sadly missed by her many friends and her wide circle of scientific acquaintances, but science as a whole will be the poorer for her death. Happily, her great contributions to knowledge remain in the scientific literature and in the work of those whom she advised and inspired.

\section{Reports and Publications}

not included in the Monthly Books Supplement

\section{Great Britain and Ireland}

Tate and Lyle Limited. Group Research and Development-Annual Report for 1972 . Pp. 65. (Reading, Berks: Tate and Lyle Limited, Group Research and Development, 1973.)
University of Oxford. Graduate Studies: Students University of Oxford. Graduate Studies: Students
under Boards of Faculties and Committees as on the under Boards of Faculties and Committees as on the
first day of Trinity Term 1973. Pp. 227-335. (Oxford: The University, 1973.) 10p. Department of the Environment. Water Pollution Research Technical Paper No. 13: Mathematical and ydraulic Modelling of Estuarine Pollution. (Proceedings of a Symposium held at the Water Pollution Research Laboratory, 18th and 19th April. 1972.) Pp. Report by the Hydrographer of the Navy 1972 p. 38. (NP 130.) (Taunton: Hydrographic Depart ment of the Ministry of Defence, 1973.) Shoe and Allied Trades Research Association.
Annual Report for 1972. Pp. iv + 173. (Kettering. Northants: Shoe and Allied Trades Research Associa(ion, 1973.)

BP Statistical Review of the World Oil Industry 1972. Pp. 24. (London: The British Petroleum Comany, Ltd., 1973.)

Propert of the Roya Medico-Psychological Association's Manpower and of Psychiatry, Special Publication No: 7 ) Pp xii 163 Ashford Kent: Headley Brothers PD. Xil Published by authority of the Royal College of
Psychiatrists.) $£ 2 ; \$ 5.35$. Genetic Studies in Mental Subnormality, By B. C. Clare Davison, Peter N. Swift, Philip F. Benson and John D. Stuđdy, (British Journal of Psychiatry, Special Publication No. 8.) Pv. 82. (Ashford, Kent: Headley Brothers, Ltd., 1973. Published by authority of the Royal College of Psychiatrists.) $\$ 2 ;$ \$5.35.
Natural Environment Rescarch Council. Institute Natural Environment Geomagnetic Bulletin No. 4: Magnetic Results 1970: Eskdalemuir, Hartland and Lerwick Observatories. $\mathrm{Pp}$ ix +154 . (London HMSO, 1973.) $£ 4$. Plastics and the Plastics Industry: a Sclcct Cata genue. Pp. 20. (London: LiNK Liaison Officer Gratis.

Department of Trade and Industry. Production and Reserves of Oil and Gas on the United Kingdom Continental Shelf: a Report to Parliament by the Minister for Industry. Pp. 12. (London: HMSO 1973.) 20p. The British Food Manufacturing Industries Research Association. Annual Report 1972. Pp. 54 Leatherhead: The British Food Manufacturing In dustries Research Association, 1973.) [165 Proceedings of the 12th NIAB Crop Confcrence, 13/15 December 1972: UK Cereal Production after Recommended Varieties 1973 . Pp. 83. L1. List of National Institute of Agricultural Botany 1973) [165 (165 Scicnce Research Council. Daresbury Nuciear Daresbury, Nr. Warrington: Daresbury Nuclear Physics Laboratory, 1973.) Countryside Commission for England and Wales. Countryside Recreation Staff-a Paper for Discussion. Pp. 13. (London: Countryside Commission 1 Cambridge Gate, Regent's Park, NW1, 1973. Gratis.

\section{Other Countries}

CRRN-European Organisation for Nuckar Research. CERN-73-4: High Accuracy, Two-Dimensional Read-Ou in Multiwire Proportional Chambers. By G. Charpak and F. Sauli. Pp. iii+10. (Geneva: CERN, 1973.) Cancer. By G. Brule, S. J. Eckhardt, T. C Hall and A. Winkler. PD. 163. 20 Sw. francs; $£ 2$; $\$ 5$. Technical Report Series No. 507: PsychogeniatricsReport of a WHO Scientific Group. Pp. 48. Sw. francs: 40D; \$1. fGeneva: WHO: London: HMSO, 1972 and 1973.) [23 US Department of Cornmerce: National Bureau of Standards. NBS Special Foreign Currency Pro gram in Yugoslavia, 1971-72. By H. Steffen Peiser. Yakowitz and Dor , Emand No. 753.) Pp. v+65. Washington, DC: Us DeNo. 753.) Pp. v+65. Washington, DC: US Department of Commerce, National Bureau of StanOffice.) 90 cents.

\section{HOW TO BUY NATURE}

The cost of one year's subscription to NATURE is:

UK \& elsewhere US \& Canada

Nature (Friday)

$\mathbf{E 1 6}$

$£ 20$

Nature \& Nature Physical Science or Nature New Biology

Nature New Biology or Nature

Physical Science

All three editions

$£ 29.50$

$£ 44$

Index (1972)

f1

$£ 1.50$

(Charges for delivery by air mail on application). Subscribers in North America may be able to claim a tax rebate against their NATURE subscription.
Editorial, Advertising and Publishing Offices of NATURE MACMILLAN JOURNALS LIMITED 4 LITTLE ESSEX STREET, LONDON WC2R 3LF

Telephone Number: 01-836 6633. Telegrams: Phusis London WC2R 3LF Telex 262024

MACMILLAN JOURNALS LIMITED

711 NATIONAL PRESS BUILDING WASHINGTON DC 20004

Telephone Number: 202-737 2355. Telex 64280

Advertisement Department

MACMILLAN JOURNALS LIMITED

4 LITTLE ESSEX STREET, LONDON WC2R 3LF

Telephone Numbers: UK 01-836 6633. USA 202-737 2355

Subscription Department

MACMILLAN JOURNALS LIMITED

BRUNEL ROAD, BASINGSTOKE, HANTS RG21 2XS Telephone Number: Basingstoke 29242

Classified advertisements

T. G. SCOTT \& SON, LIMITED

1 CLEMENT'S INN, LONDON WC2A 2ED

Telephone Number: 01-242 6264/01-405 4743

Telegrams: Textualist London WC2A 2ED

Registered as a newspaper at the Post Office

Copyright (C) Macmillan Journals Limited, August 241973 